RESEARCH ARTICLE

\title{
CMCE Propolis Extract Improve Caspase 3 Expressions of The Hepatocytes and IL-6 Levels in Rats Exposed with CC14
}

\author{
Chalid Firdaus $^{\mathbf{1}^{*}}$, Chodidjah ${ }^{1}$, Taufiqurrachman Nasihun ${ }^{1}$ \\ ${ }^{1}$ Master of Biomedical Sciences, Faculty of Medicine, Sultan Agung Islamic University, Semarang \\ * Corresponding author email: firdauschalid@gmail.com/+6285726888887
}

\begin{abstract}
Introduction: Liver plays an important role in the metabolic processes possibly exposed to the toxic materials. One of those hepatotoxic substances is carbon tetrachloride. The propolis extract contains the balsamic active substances, CAPE compounds and flavonoids. Flavonoids can prevent from the apoptosis and reduce the inflammation. Objective: To validate propolis extract's (CMCE method) ability in improving caspase 3 expressions of hepatocytes and IL-6 levels in Wistar male rats induced with carbon tetrachloride.

Methods: An experimental study with a post-test only control group design applied to the study. The research subjects were 28 male Wistar rats, divided into four groups. The negative control group $(C N-G)$ was only injected with CCl4, while the experimental groups were administered with the CMCE propolis at the dosages of $3.6 \mathrm{mg} / 200 \mathrm{~g}$ (CM3-G), $7.2 \mathrm{mg} / 200 \mathrm{~g}$ (CM7-G), and $14.4 \mathrm{mg} / 200 \mathrm{~g}$ (CM14-G). The CMCE propolis extract was administered for 14 days and on day 14, the CCl4 was then given. The caspase 3 expression of hepatocytes was measured using HE liver cell preparations, while the IL-6 levels were measured using ELISA method.

Results: The results of Mann-Whitney U statistical analysis showed that the hepatocytes' caspase 3 expressions in CM14-G (2.77 \pm 0.531$)$, CM7-G (3.14 \pm 0.378$)$, and CM3-G $(4.22 \pm 0.690)$ were lower than those in $C N-G(5.43 \pm 0.535), p<0.05$. Meanwhile, the Post Hoc LSD analysis Results showed that IL-6 levels in CM14-G (55.032 \pm 9.336$), C M 7-G$ (78.362 \pm 8.313$)$, and CM3-G (114.975 \pm 10.359$)$ were lower those in CN-G (180.301 \pm 5.428), $p<0.05$.

Conclusion: the administration of propolis extract (CMCE method) improve the caspase 3 expressions of hepatocytes and Il-6 levels in Wistar male rats induced with carbon tetrachloride.
\end{abstract}

Keywords: Propolis extract (CMCE method), caspase 3 expression in hepatocytes, IL-6 levels.

\begin{abstract}
ABSTRAK
Latar Belakang: Hepar berperan dalam proses metabolisme yang dapat terpapar oleh bahan toksik. Salah satu zat hepatotoksik adalah carbon tetracloride. Ekstrak propolis mengandung zat aktif balsamic, senyawa CAPE dan flavonoid. Flavonoid dapat mencegah apoptosis dan menurunkan inflamasi. Tujuan: Membuktikan pengaruh pemberian ekstrak propolis (Metode CMCE) terhadap ekspresi caspase 3 sel hati dan kadar Il-6 pada tikus jantan wistar yang diinduksi carbon tetrachloride.

Metode: Penelitian eksperimental dengan desain penelitian post test only control group design, sebanyak 28 ekor tikus jantan wistar, dibagi menjadi empat kelompok. Kelompok kontrol negative (CN-G) hanya (diinjeksi CCL4) dan kelompok perlakuan yang diberikan CMCE propolis dosis 3,6 mg/200g (CM3-G), dosis 7,2 mg/200g (CM7-G), dan dosis 14,4 mg/200g (CM14-G) secara oral. Pemberian ekstrak propolis diberikan selama 14 hari, dan pada hari ke-14 diberikan CCL4. Ekspresi caspase 3 sel diukur dengan preparat sel hepar dengan perwanaan HE, sedangkan kadar IL-6 diukur mengunakan metode ELISA.

Hasil: Hasil analisa statistik Mann-Whitney U menunjukkan bahwa ekspresi caspase 3 sel hati kelompok CM14-G (2,77 $\pm 0,531)$, CM7-G $(3,14 \pm 0,378)$, dan CM3-G $(4,22 \pm 0,690)$ lebih rendah bermakna dibanding CN-G $(5,43 \pm 0,535), \mathrm{p}<0,05$. Hasil uji Post Hoc LSD menunjukkan bahwa kadar IL-6 pada kelompok CM14-G $(55,032 \pm 9,336)$, CM7-G $(78,362 \pm 8,313)$, dan CM3-G $(114,975 \pm 10,359)$ lebih rendah bermakna dibanding CN-G $(180,301 \pm 5,428), \mathrm{p}<0,05$.

Kesimpulan: Pemberian ekstrak propolis (Metode CMCE) mampu menurunkan ekspresi caspase 3 sel hati dan kadar Il-6 pada tikus jantan wistar di induksi carbon tetrachloride.
\end{abstract}

Kata Kunci: Ekstrak propolis (Metode CMCE), Ekspresi caspase 3 sel hati, Kadar IL-6.

\section{INTRODUCTION}

Liver is an essential organ for human body. As a metabolism organ, liver has function in synthesis, storage, metabolism and detoxification processes (Yenny et al., 2011). Free radicals underlying various cells and tissues damages, including liver, in oxidative stress. Thus, to prevent the damages caused by free radicals to the body, additional (exogenous) antioxidants from outside of the body is greatly required (Tjok Istri Anom S and Wibawa, 2012). Propolis is believed containing antioxidant able to suppress free radicals. However, it is still lacking of evidence that the administration of propolis able to improve the hepatocytes' damages caused by the apoptosis and reducing interleukin- 6

Copyright @ 2020 Authors. This is an open access article distributed under the terms of the Creative Commons Attribution-NonCommercialShareAlike 4.0 International License (http://creativecommons.org/licenses/by-nc-sa/4.0/), which permits unrestricted non-commercial use, distribution, and reproduction in any medium, provided the original author and source are properly cited. 
Firdaus, et al.

(IL-6) level in vivo.

Liver disease still becomes a serious problem, especially in the developing countries, and causes the increasing illness and death rates throughout the world. It is estimated that more than one-third of the world's inhabitants have been infected by the hepatitis B virus. Besides, approximately $5 \%$ of the population has become the carriers of chronic hepatitis B virus (HBV), and generally, almost $25 \%$ of carriers has experienced more severe liver diseases, such as chronic hepatitis, cirrhosis, and primary hepatocellular carcinoma (Kumar, Abbas and Fausto, 2010). Hepatotoxic is the main effect of carbon tetrachloride (CCl4) exposure on humans and animals (Bhadauria, 2012). The histopathological examination shows that the influence of CCl4 administration may cause more extensive inflammatory processes in liver (Krisnansari, Sulistyo and Kusdaryanto, 2014). Besides, CCl4 administration may also trigger the formation of excessive free radicals, hence the oxidative stress may result in liver damages and even dysfunctions (Widianto and Rosyidah, 2017).

Liver cell damages caused by the $\mathrm{CCl} 4$ exposure are also characterized with the inflammation followed by the secretion of proinflammatory cytokines, such as IL-6 and tumor necrosis factor alpha (TNF- $\alpha$ ) (Soroy et al., 2014). The national prevalence in each country throughout the world ranged between $0.5 \%$ in the US and North Europe, while in the Asian areas was 10\%. In 2010, the prevalence of hepatitis A virus infection disease reached $9.3 \%$ of 237.6 million inhabitants. In South Sumatera in 2007 with 7.019 .964 inhabitants, the prevalence of hepatitis A was $0.2-1.9 \%$. Indonesia is a country with the prevalence ranked the highest endemic rate of hepatitis $B$ of more than 8 percent that 1.5 million Indonesian people potentially suffer from the liver cancer (Kementerian Kesehatan Republik Indonesia, 2010). The death rate caused by the liver diseases may continuously increase, if not well managed.

Human body has limited antioxidants. Thus, if free radicals are excessively exposed, the body requires more antioxidants from outside the body (exogenous). One natural exogenous antioxidant is propolis. Many studies show that propolis has antibacterial, antifungal, antiviral, and hepatoprotective activities (Sforcin and Bankova, 2011). One hepatotoxic substance causing the chronic liver disease is carbon tetrachloride (CCl4). The CCl4 administration may cause the oxidative stress processes, hormonal balance disorders, and chronic inflammation reactions triggering the secretion of plenty pro-inflammatory cytokines, including interleukin-6 (Sumarmi, 2018). Propolis also has a neuroprotector property as reported in the research conducted on the rats' focal cerebral ischemia model resulting in significantly reduced caspase-3 expression (Harahap, Irfannuddin and Murti, 2018).

The other studies also show that propolis extract is proven effective in recovering dengue fever patients, based on the laboratory examination, clinical conditions and the shortening length of patients' treatment periods (Soroy et al., 2014). Moreover, the administration of propolis extract at the dosages of 0.054 gr and 0.108 gr shows the hepatoprotective activities to the liver damages induced by CCl4, showed by decreasing IL- 6 , and SOD levels, also improvement in liver cell damage percentages (Krisnansari, Sulistyo and Kusdaryanto, 2014). More studies also show that propolis affects the pro apoptotic proteins (Bax, Bak, caspase 3 , cytochrome C), cell differentiation's protein regulators ( $\mathrm{p} 38, \mathrm{p} 56$, p21, cyclin-dependent kinase), and targets which have an important role in the cancer-related inflammation, such as NFKB and COX2. The administration of propolis extract increase the caspase 3 expression in the WiDr cell cultures (Anandani, Kusnanto and Purwanto, 2018).

The main components of propolis are flavonoid and phenolic acid, including Caffeic acid phenetyl ester (CAPE), in which almost $50 \%$ of all propolis compositions contain CAPE. Flavonoid is the biggest natural phenolic group covering many pigments generally contained in all plants (Mihai et al., 2011). CAPE significantly inhibits the production of cytokines and lymphokines, including TNF- $\alpha$, IL-2, IL-10, IL12 , and IFN, and the proliferation of T-cells. Proinflammatory cytokines, IL-1, IL- 6 , and TNF- $\alpha$ are responsible for changes in the body's metabolic and pathogenic attacks (Soroy et al., 2014). Since CAPE and flavonoid contained in the propolis extract have a significant effect in decreasing the pro-inflammatory cytokines, this research aims at validating the effect of propolis administrations in improving caspase 3 expressions of hepatocytes and IL-6 levels in Wistar male rats induced with carbon tetrachloride.

\section{METHODS}

This experimental research used a "Post Test Only Control Group Design". Twenty eight Wistar male rats aged 8 weeks, weighed 180-200 g were used, and then divided into four groups. Negative control group $(\mathrm{CN}-\mathrm{G})$ was administered with $\mathrm{CCl} 4$ at the dosage of $0.4 \mathrm{ml} / 200 \mathrm{gr}$ in day 14 , while the experimental groups were administered with propolis extract at the dosages of $3.6 \mathrm{mg} / 200 \mathrm{gr}$ (CM3-G), $7.2 \mathrm{mg} / 200 \mathrm{gr}$ (CM7-G), $14.4 \mathrm{mg} / \mathrm{gr}$ (CM14-G) for 14 days, and then administered with $\mathrm{CCl} 4$ in day 14 at the dosage of 
http://jurnal.unissula.ac.id/index.php/sainsmedika

CMCE Propolis Extract Improve Caspase 3 Expressions of The Hepatocytes and IL-6 Levels in Rats Exposed with CCl4 ...

$0.4 \mathrm{ml} / \mathrm{gr}$. This research was conducted at the Food and Nutrition Research Center Laboratory (known as PSPG/Laboratorium Pusat Studi Pangan dan Gizi) of Universitas Gajah Mada Yogyakarta and Sultan Agung Islamic Hospital Semarang. This research was conducted after obtaining permit from the Bioethics Committee of Medical Faculty, Universitas Islam Sultan Agung Semarang, No. 270/V/2019/Komisi bioetik.

\section{Propolis Extract and Dosage}

The propolis used in this research was the propolis extract obtained from High Desert Indonesia. The propolis ethanol extract was made using the CMCE (Continuous Multi-stage Countercurrent Extraction) technique. The multistage extraction is the development of one stage extraction. The rafinat secreted from the first stage was mixed with the fresh solvent in the second stage and then was mixed with the fresh solvent in the third stage. The extract obtained from the first stage was combined with the extract obtained from the second and the third stage. The final results were the extracts $(\mathrm{E} 1+\mathrm{E} 2+\mathrm{E} 3)$ and Rafinat R3. The composition of components in $\mathrm{E}$ and $\mathrm{R}$ flows had been balanced that $\mathrm{E}$ and $\mathrm{R}$ were located in the balance curve: E1 was balanced with R1, E2 was balanced with R2, and E3 was balanced with R3. The propolis extract was then diluted with aquadest 1:10. The volume of propolis extract was orally administered as much as $1 \mathrm{ml}$. The volume permitted to be administered based on the normal volume of rat's stomach was $3-5 \mathrm{ml}$. Dosage I with the calculation of dosage conversion in rats (Body Mass $=200$ grams), was $200 \mathrm{mg} \times 0.018=3.6 \mathrm{mg} / 200 \mathrm{~g}$ rat. Dosage II with the calculation of dosage conversion in rats was $400 \mathrm{mg} \times 0.018=7.2 \mathrm{mg} / 200 \mathrm{~g}$ rat. Dosage III with the calculation of dosage conversion in rats was $800 \mathrm{mg}$ x $0.018=14.4 \mathrm{mg} / 200 \mathrm{~g}$ rat.

\section{Preparation of Liver's Specimens and Caspase 3 Expression Examination}

Liver apoptotic examination began by making the liver specimen preparation. The liver specimen preparation making stages are explained as follows. Tissue fixation stage began by entirely cleaning the liver using PBS $1 \mathrm{x}$ and then put in the fixative for 1 hour. Furthermore, the liver was cut into the size of 1 $\mathrm{x} 1 \mathrm{~cm}$. The specimen was once again immersed into the fixative for $<24$ hours. The specimen was then repeatedly cleaned using alcohol $50 \%$ without holding and pressing the specimen. If stored for $>24$ hours, the specimen should be immersed in alcohol $70 \%$ and then cleaned once again using alcohol $70 \%$. Fixation aimed at minimalizing or stopping the tissue's autocatalyst process. The next step was making the paraffin block. The specimen was dehydrated in alcohol $85 \%$ for $1-2$ hours, alcohol $96 \%$ for $1-2$ hours, and alcohol $100 \%$ for 2-3 hours. The specimen was cleared using xylol:alcohol $100 \%=1: 3$ for 1 hour, xylol:alcohol $100 \%=2: 2$ for 1 hour, xylol:alcohol $100 \%=3: 1$ for 1 hour, pure xylol I for 1 hour, and pure xylol II for 1 hour. Specimen infiltration was made in the oven using xylol:paraffin 1:1 (45-500C) for 1 hour, paraffin I (65-700C) for 1 hour, and paraffin II (65-700C) for 1 hour. This process aimed at cleaning the tissues from the alcohol remains to ease the attachment using the mounting medium. The block was made using paper. The specimen was put into the paper box, added with liquid paraffin, and then labeled. The paraffin was then cooled using cold water. This paraffin blocking aimed at simplifying the tissue cutting using microtome with the thickness of 5-10 micron. The next was paraffin block cutting. The well- prepared paraffin block was then sliced using the rotary microtome. The liver tissue slices were in the thickness of $4 \mu \mathrm{m}$. The mounting was then performed in the object glass/slide using gelatin $5 \%$. The staining was next performed. After sliced, the paraffin block was then put on top of the object glass/ slide. Since the occurring layer was still covered, the paraffin should be removed by immersing the layer in the dehydration solution (alcohol, xylol). Still in the dehydration series, staining was made in order that the observed tissues looked clear. Haematoxilin eosin was the solution used.

The hepatocytes underwent apoptosis was observed using an Olympus microscope and the slide blot was pictured with the circular magnification of 400x. The cells experiencing apoptosis was then observed based on the characteristics of shrinkage cells, condensation-experiencing nucleus, and formed apoptotic bodies.

\section{IL-6 Level Measurement}

IL-6 level measurement used the ELISA method. The samples used were 28 serum samples of wistar male rats. The IL- 6 examination principle was that the sample was reacted with antibody containing specific antibody against IL-6, then Horseradish Peroxidase (HRP) was added and Avidin was incubated for 1 hour in $37^{\circ} \mathrm{C}$. The IL-6 level was measured using spectrophotometer with the wave length of $450 \mathrm{~nm}$.

\section{Statistical Analysis}

The data analysis on the caspase 3 expression of hepatocytes was analyzed using Kruskal Wallis 
Firdaus, et al.

http://jurnal.unissula.ac.id/index.php/sainsmedika

Table 1. Average IL-6 levels and caspase 3 expressions of hepatocytes in each Group

\begin{tabular}{|c|c|c|c|c|c|}
\hline \multirow[b]{2}{*}{ Variable } & \multicolumn{4}{|c|}{ Group } & \multirow[b]{2}{*}{$\mathbf{P}$} \\
\hline & $\begin{array}{c}\mathrm{CN}-\mathrm{G} \\
\mathrm{N}=5, \chi( \pm \mathrm{SD})\end{array}$ & $\begin{array}{c}\text { CM3-G } \\
\mathrm{N}=5, \chi( \pm \mathrm{SD})\end{array}$ & $\begin{array}{c}\text { CM7-G } \\
\mathrm{N}=5, \chi(+\mathrm{SD})\end{array}$ & $\begin{array}{c}\text { CM14-G } \\
\mathrm{N}=5, \chi( \pm \mathrm{SD})\end{array}$ & \\
\hline $\begin{array}{l}\text { Caspase } 3 \text { expression } \\
\text { (\%) }\end{array}$ & $\begin{array}{c}5.43 \\
\pm 0.535\end{array}$ & $\begin{array}{c}4.22 \\
\pm 0.690\end{array}$ & $\begin{array}{c}3.14 \\
\pm 0.378\end{array}$ & $\begin{array}{c}2.77 \\
\pm 0.531\end{array}$ & 0.001 * \\
\hline $\begin{array}{l}\text { IL-6 Level } \\
(\mathrm{pg} / \mathrm{ml})\end{array}$ & $\begin{array}{c}180.301 \\
\pm 5.428\end{array}$ & $\begin{array}{l}114.975 \\
\pm 10.359\end{array}$ & $\begin{array}{c}78.362 \\
\pm 8.313\end{array}$ & $\begin{array}{l}55.032 \\
\pm 9.336\end{array}$ & $0.000^{* *}$ \\
\hline
\end{tabular}

Note: * Kruskal Wallis; ** One Way Anova

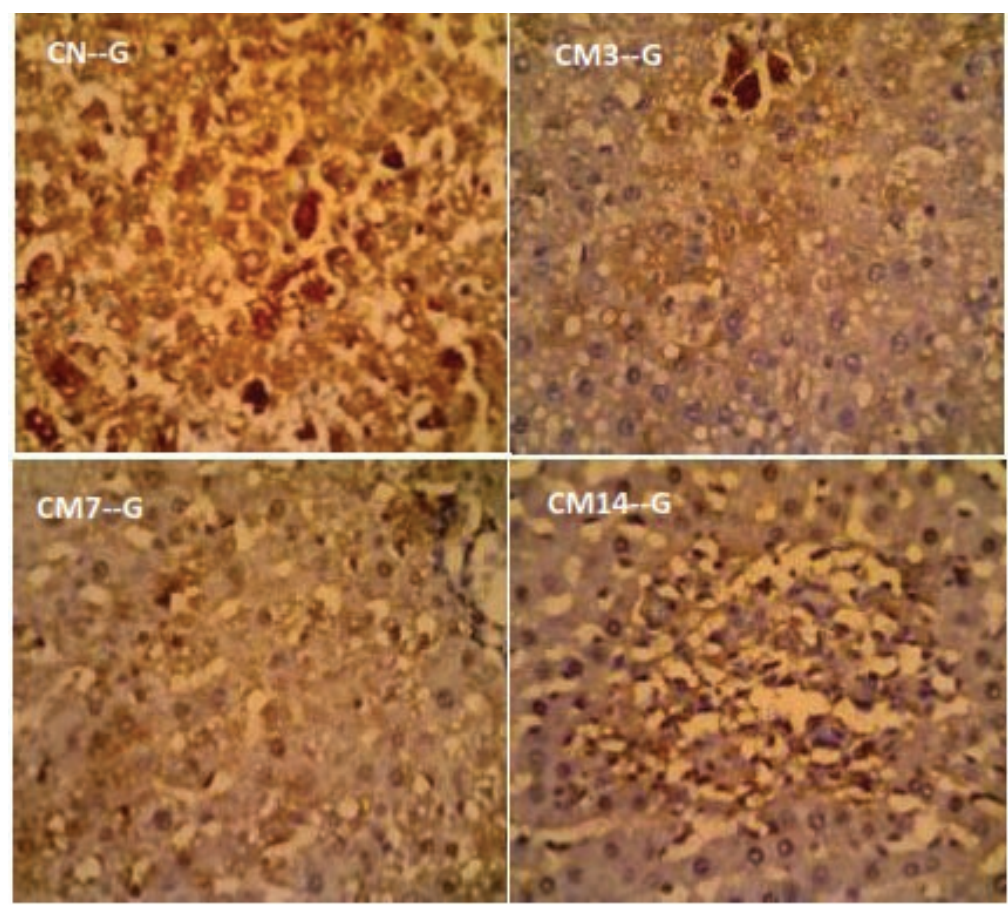

Figure 1. Caspase 3 expression in group CN-G; CM3-G; CM7-G; and CM14-G. The brown color indicated the caspase 3 expression expression. positive
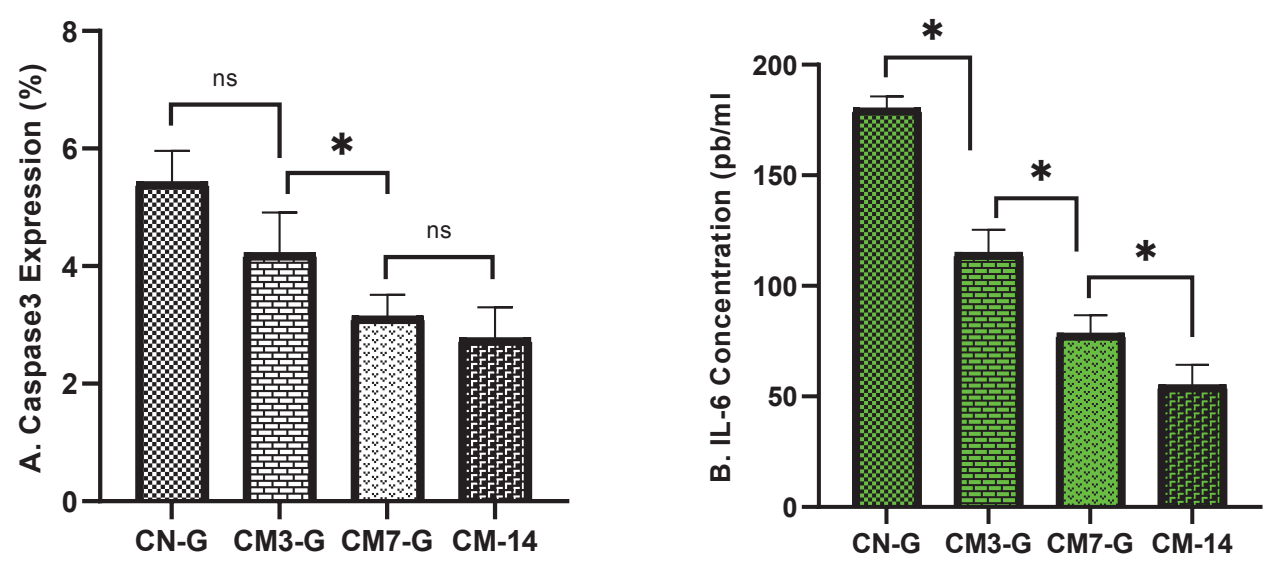

Figure 2. A. Caspase 3 Expression in Liver, and B. IL-6 Concentration. Post Hoc Analysis: * p<0.05; ns: not significant 
http://jurnal.unissula.ac.id/index.php/sainsmedika

CMCE Propolis Extract Improve Caspase 3 Expressions of The Hepatocytes and IL-6 Levels in Rats Exposed with CCl4 ...

continued with Mann-Whitney U. Meanwhile, the IL-6 level was analyzed using the One Way Anova test and then continued with the Post Hoc LSD. The statistical analysis result was considered significant if the $\mathrm{p}$-value was $<0.05$.

\section{RESULT}

This research used propolis extract daily administered for 14 days, and in day 14, the CC14 was administered to the Wistar male rats. The average IL-6 levels and caspase 3 expressions of hepatocytes were presented in the following table 1.

The results of this research showed that the average value caspase 3 expressions of hepatocytes in CN-G was the highest, respectively followed by that in CM3-G and CM7-G, while the lowest was that in CM14-G. Since the caspase 3 expression hepatocytes data were not normally distributed, Kruskal Wallis test was then performed to see the differences between groups. The analysis result showed that caspase 3 expression between groups was significantly different with $\mathrm{p}<0.05$.

On the other hand, the highest level of IL-6 level found in $\mathrm{CN}-\mathrm{G}$, respectively followed by that in CM3-G and CM7-G, while the lowest level was that in CM14$\mathrm{G}$. As the caspase 3 expression of hepatocytes data were normally distributed, one way anova test was then performed. The analysis result showed that the IL-6 level between groups was significantly different with $p<0.05$. To know the group which had a significant difference, each was then examined using Mann-Whitney U and Post Hoc test as explained below.

\section{Caspase 3 Expression of Hepatocytes}

Mann-Whitney U test result showed that caspase 3 expression in CM7-G and CM14-G was significantly lower than that in $\mathrm{CN}-\mathrm{G}$ with $\mathrm{p}<0.05$. Meanwhile, the caspase 3 expression in CM3-G was lower, yet not significantly different than that in CN-G with $p>0.05$. Similarly, the caspase 3 expression in CM14-G was lower than that in CM7-G with $\mathrm{p}>0.05$ (figure 1, 2A).

This result showed that propolis extract administration with the dosages of $3.6 \mathrm{mg} / 200 \mathrm{~g}, 7.2$ $\mathrm{mg} / 200 \mathrm{~g}$, and $14.4 \mathrm{mg} / 200 \mathrm{~g}$ reduced the caspase 3 expression of hepatocytes due to the $\mathrm{CCl} 4$ injection. The propolis extract with the dosages of $7.2 \mathrm{mg} / 200 \mathrm{~g}$ and $14.4 \mathrm{mg} / 200 \mathrm{~g}$ showed better results than that with the dosage of $3.6 \mathrm{mg} / 200 \mathrm{~g}$.

\section{IL-6 Level}

Post Hoc test result showed that the average IL-6 level in CM3-G, CM7-G, and CM14-G was significantly lower than that in $\mathrm{CN}-\mathrm{G}$ with $\mathrm{p}<0.05$. The average IL-6 level in CM14-G was significantly lower than that in

CM7-G and CM3-G with $p<0.05$. Similarly, the IL-6 level in CM-7G was lower than that in C3-G with $\mathrm{p}<0.05$ (figure 3 ). The Post Hoc LSD test result in IL-6 level showed that the propolis extract at the dosages of $3.6 \mathrm{mg} / 200 \mathrm{~g}, 7.2 \mathrm{mg} / 200 \mathrm{~g}$, and $14.4 \mathrm{mg} / 200 \mathrm{~g}$ could reduce the IL- 6 level in the Wistar male rats induced with carbon tetrachloride (figure 1).

\section{DISCUSSION}

The results of this research showed that the administration of $\mathrm{CCl} 4$ may cause hepatocytes damages mediated by apoptosis. It was shown by the high IL6 level as the proinflammatory marker and caspase 3 expression as apoptosis marker in the negative control group and was significantly different with that in the propolis group. Moreover, the administration of propolis extract in this research could significantly reduce the IL- 6 level and caspase 3 expression after injected with the CCl4.

This research result also showed that the caspase 3 expressions of hepatocytes after the administration of propolis at the dosages of $7.2 \mathrm{mg} / 200 \mathrm{~g}$ and 14.4 $\mathrm{mg} / 200 \mathrm{~g}$ experienced a significant reduction. The result of this research was supported by the previous studies stating that the administration of propolis affected the caspase 3 expressions in WiDr cell cultures (Anandani, Kusnanto and Purwanto, 2018) as the propolis had a high flavonoid content functioning as neuroprotector. The result of research conducted by Dewi, on rats with focal cerebral ischemia showed that flavonoids could significantly reduce the caspase-3 expression (Dewi, Ali and Purnomo, 2016). It explained that the caspase 3 decreasing expression was as the reflection of cells' decreasing apoptosis (Hidayat et al., 2011). The propolis extracts could not significantly reduce the hepatocytes' caspase 3 expressions at the dosage of $3.6 \mathrm{mg} / 200 \mathrm{~g}$, yet there was a difference with the result of positive control. It was proven that the lipid peroxidation and hepatocytes' damages could be significantly suppressed by the antioxidant supplementations, such as flavonoid, silymarin, or vitamin E (Soroy et al., 2014). Propolis extract is bee product containing high active composition of flavonoid functioning as antioxidant. Propolis has antioxidant function able to prevent damage from free radicals compounds. Propolis extract also has the function as the toxic neutralizer since propolis has various contents to possibly clean the pollutants and toxic in the body. Thus, the metabolism of cells can work optimally (Krisnansari, Sulistyo and Kusdaryanto, 2014). Some researchers have also reported that the propolis extract containing CAPE showed the inhibition influence in the production 
Firdaus, et al.

of pro-inflammatory cytokines (interleukin (IL)-1 $\beta$, TNF- $\alpha$, and MCP. Propolis contains neuroprotective components through the properties of antioxidant, antiinflammatory and immunomodulator (Krisnansari, Sulistyo and Kusdaryanto, 2014).

The result of this research showed that IL-6 level in the administration of propolis extract at the dosages of $3.6 \mathrm{mg} / 200 \mathrm{~g}, 7.2 \mathrm{mg} / 200 \mathrm{~g}$ and $14.4 \mathrm{mg} / 200 \mathrm{~g}$ experienced a significant reduction. The result of this research also was also in accordance with the previous research stating that the administration of propolis at the dosages of $0.054 \mathrm{~g}$ and $0.108 \mathrm{~g}$ showed the hepatoprotective activity to the liver damages inducted with CCl4 shown by the reduction of IL-6 and SOD levels and hepatocytes' damage percentage (Krisnansari, Sulistyo and Kusdaryanto, 2014). This activity was due to the existence of phenolic compounds contained in propolis in the form of flavonoid which can cover the cell structures that the body has the defense against the microorganisms. Flavonoid greatly influences the development of immune system in which flavonoid is an antioxidant contained in the propolis. The other research mentioned that propolis could decrease the prostaglandins, leukotrienes, proinflammatory cytokines (TNF- $\alpha$, IL-6, IL-1, IL-10, and IL-8) (Lee et al., 2017). Propolis with its various benefits may increase the macrophage activity mediated by the stimulation of cytokines production, such as IL-6 and TNF- $\alpha$ in the rats. The content of propolis extract, that is, CAPE (Caffeic Acid Phenethyl Ester), has the antiinflammatory activity by inhibiting the arachidonate acid release from the cell membrane and suppressing the COX-1 and COX-2 enzyme activity. Besides, CAPE $(1.5$ and $10 \mu \mathrm{M})$ may also inhibit the deoxyribonucleic acid (DNA) binding activity, NFkB transcription, and activator of protein-1 (AP-1) without affecting protein degradation as the $\mathrm{NFkB}$ inhibitor located in the cytoplasm. Thus, propolis has an activity as immunomodulator and anti-inflammatory (Bhadauria, 2012).

\section{CONCLUSION}

The administration of Propolis extract (CMCE method) possibly decreased the hepatocytes' caspase 3 expressions and IL-6 levels in the Wistar male rats inducted with carbon tetrachloride.

\section{CONFLICT OF INTEREST}

There is no conflict of interest in this publication.

\section{ACKNOWLEDGMENT}

We highly appreciate and thank the laboratory staffs of the Center for Food and Nutrition Studies, Gadjah Mada University for their hard work and guidance in maintaining and testing samples during this research.

\section{REFERENCES}

Anandani, E. T., Kusnanto, P. and Purwanto, B. (2018) 'Pengaruh Ekstrak Propolis Terhadap Ekspresi Caspase 3, Proliferasi Dan Induksi Apoptosis Pada Sel Kanker Kolon (Cell Line WiDr) [The Influence of Propolis Extract to the Caspase 3 Expressions and Apostosis Induction in the colon cancer cells]', Biomedika, 9(2), pp. 23-30. doi: 10.23917/biomedika.v9i2.5839.

Bhadauria, M. (2012) 'Propolis prevents hepatorenal injury induced by chronic exposure to carbon tetrachloride', Evidence-based Complementary and Alternative Medicine, 2012, pp. 1-12. doi: $10.1155 / 2012 / 235358$.

Dewi, A. C., Ali, M. and Purnomo, H. (2016) 'Efek Ekstrak Propolis terhadap Ekspresi TNF- $\alpha$, Apoptosis dan Nekrosis Jaringan Otak Tikus Model Traumatic Brain Injury ( TBI ) The Effects of Propolis Extract on Brain TNF- $\alpha$ Expression, Apoptosis and Necrosis in Rat Model of Traumatic Brain Injury', Jurnal Kedokteran Brawijaya, 29(2), pp. 117-124.

Harahap, H., Irfannuddin, I. and Murti, K. (2018) 'Pengaruh Diet Ketogenik Terhadap Ekspresi Ki67, Caspase-3, Dan Mda Pada Jaringan Hati [The Influence of Ketogenic Diet on the Expression of Ki-67, Caspase-3, and Mda in Liver Tissues]', Jurnal Kedokteran dan Kesehatan [Journal of Medicine and Health], 6(2), pp. 185-194.

Hidayat, A. et al. (2011) 'Ekspresi Bcl-2 dan Caspase3 Pascapaparan Hipoksia Hipobarik Intermiten Bcl-2 and Caspase-3 Expression Post Exposure of Intermittent Hypobaric Hypoxia', Majalah Kedokteran Bandun, pp. 166-170.

Kementerian Kesehatan Republik Indonesia (2010) Hepatitis masalah kesehatan dunia [World Problems on Heparitics]. Jakarta.

Krisnansari, D., Sulistyo, H. and Kusdaryanto, W. D. (2014) 'Potensi Hepatoprotektor Propolis Terhadap Hepar Tikus Putih (Rattus Norvegicus) Yang Diinduksi Karbon Tetraklorida', Jurnal Ners, 9(2), pp. 270-278. 
http://jurnal.unissula.ac.id/index.php/sainsmedika

CMCE Propolis Extract Improve Caspase 3 Expressions of The Hepatocytes and IL-6 Levels in Rats Exposed with CCl4 ...

Kumar, V., Abbas, A. K. and Fausto, N. (2010) Adaptasi, cedera dan kematian sel [Cell Adaptation, Injury, and Deatth] (in Robbins and Cotran: dasar patologi penyakit [Basic Pathology of Diseases]). 7th edn. Jakarta: EGC.

Lee, C. H. et al. (2017) 'Protective mechanism of glycyrrhizin on acute liver injury induced by carbon tetrachloride in mice', Biology Pharmacology Bulletin, 30(10), pp. 1898-1904. doi: $10.1248 /$ bpb.30.1898.

Mihai, C. M. et al. (2011) 'Correlation between Polyphenolic Profile and Antioxidant Activity of Propolis from Transylvania', Scientific Paper: Animal Science and Biotechnology, 44(2), pp. 100-103.

Sforcin, J. M. and Bankova, V. (2011) 'Propolis: Is there a potential for the development of new drugs?', Journal of Ethnopharmacology, 133(2), pp. 253260. doi: 10.1016/j.jep.2010.10.032.

Soroy, L. et al. (2014) 'The effect of a unique propolis compound (PropoelixTM) on clinical outcomes in patients with dengue hemorrhagic fever', Infection and Drug Resistance, 7, pp. 323-329. doi: 10.2147/IDR.S71505.
Sumarmi (2018) Korelasi CRP dengan Interleukin 10 Pasien Sirosis Hati Dekompensata [The Correlation of CRP with the interleukin of 10 patients with Decompensated Liver Cirrhosis]. Universitas Sebelas Maret.

Tjok Istri Anom S and Wibawa, I. D. N. (2012) Pendekatan diagnosis dan terapi fibrosis hati. Denpasar: Section/SMF Internal Medical Science, Medical Faculty, Universitas Udayana.

Widianto, S. and Rosyidah, D. U. (2017) Pengaruh Pemberian Ekstrak Etanol 70\% Stroberi (Fragaria X Annanassa Duchesne) Terhadap Kerusakan Morfologi Hepar Mencit (Mus Musculus) Yang Diinduksi Parasetamol Dosis Toksik [The Influence of Administration of Ethanol Extract $70 \%$ of Strawberry (Fragaria. Universitas Muhammadiyah Surakarta.

Yenny et al. (2011) 'Efek schizandrine C terhadap kerusakan hati akibat pemberian parasetamol pada tikus', Universa Medicina, 24(4), pp. 161166. 